\title{
Hubungan rasio netrofil limfosit pada anak penderita diare akut tanpa dehidrasi dan dengan dehidrasi di RSUP Prof. Dr. R. D. Kandou Manado
}

\author{
${ }^{1}$ Darulisman Samad \\ ${ }^{2}$ Max F. J Mantik, \\ ${ }^{2}$ Jeanette I. C. Manoppo
}

\author{
${ }^{1}$ Kandidat Skripsi Fakultas Kedokteran Universitas Sam Ratulangi Manado \\ ${ }^{2}$ Bagian Ilmu Kesehatan Anak Fakultas Kedokteran Universitas Sam Ratulangi \\ RSUP Prof. Dr. R. D. Kandou Manado \\ Email: dsamad_11_061@yahoo.com
}

\begin{abstract}
Diarrhea is a major cause of morbidity and mortality in children worldwide. In Indonesia, diarrhea is still one of the major public health problems. High population growth rate and mothers' knowledge about diarrhea are very important. Hematology examination, such as neutrophil and lymphocyte ratio, is suggested for acute diarrhea. This was a survey analytical retrospective study using medical record at the Department of Pediatrics Prof Dr. R. D. Kandou Hospital Manado in December 2014. The results showed that patients' age groups were: 6-12 months (average 8.5 months), 13-24 months (average 16.5 months), and 2536 months of age (average 33.3 months). Children who suffered from dehydration and without dehydration were 14 and 26 children respectively. The chi-square test of neutrophil lymphocyte ratio in diarrhea patients with dehydration and without dehydration showed a $\mathrm{p}$ value 0.058. Conclusion: There was no relationship between neutrophil lymphocyte ratio in children who suffered from acute diarrhea with dehydration and without dehydration.
\end{abstract}

Keywords: neutrophil lymphocyte ratio, acute diarrhea with dehydration and without dehydration.

\begin{abstract}
Abstrak: Penyakit diare adalah salah satu penyebab utama morbiditas dan mortalitas pada anak di seluruh dunia. Di Indonesia, diare masih merupakan salah satu masalah kesehatan masyarakat utama. Angka pertumbuhan penduduk yang tinggi serta pengetahuan mengenai diare penting untuk diketahui ibu. Salah satu pemeriksaan penunjang yang disarankan ialah pemeriksaan hematologi, yaitu hitung rasio netrofil dan limfosit. Jenis penelitian ini survei analitik retrospektif dengan menggunakan rekam medis di Bagian Ilmu Kesehatan anak RSUP Prof. Dr. R. D. Kandou Manado bulan Desember 2014. Hasil penelitian memperlihatkan usia pasien di kelompok umur 6-12 bulan (rerata 8,5 bulan), umur 13-24 bulan (rerata 16,5 bulan), dan umur 25-36 bulan (rerata 33,3 bulan). Anak yang menderita dehidrasi didapatkan 14 orang dan tanpa dehidrasi 26 orang. Uji chi-square rasio netrofil limfosit pada diare dengan dehidrasi dan tanpa dehidrasi menunjukkan nilai $p=0,058$. Simpulan: Tidak terdapat hubungan rasio netrofil limfosit pada anak penderita diare akut dengan dehidrasi dan tanpa dehidrasi.
\end{abstract}

Kata kunci: rasio netrofil limfosit, diare akut dengan dehidrasi dan tanpa dehidrasi

Penyakit diare adalah salah satu penyebab utama morbiditas dan mortalitas pada anak di seluruh dunia. Di Amerika Serikat, 2035 juta kejadian diare terjadi seriap tahun.
Mekanisme penularan utama untuk patogen diare ialah tinja-mulut, dengan makanan dan air yang merupakan penghantar umumnya. ${ }^{1}$ 
Analisis World Health Organization berdasarkan data survei memperkirakan setiap tahunnya lebih dari 1,3 miliar episode diare pada golongan umur balita terjadi di Asia, Afrika, dan negara Amerika Latin. Diperkirakan juga setiap tahunnya terjadi 3 juta kematian diare pada golongan umur balita (terjadi 57. 533 kematian setiap minggu, 8.219 kematian setiap hari, 342 kematian setiap jam, atau 6 kematian setiap menitnya), sekitar 80\% kematian terjadi pada golongan umur di bawah 2 tahun. ${ }^{2}$

Di Indonesia, diare masih merupakan salah satu masalah kesehatan masyarakat utama. Hal ini disebabkan masih tingginya angka kesakitan dan menimbulkan banyak kematian terutama pada bayi dan balita, serta sering menimbulkan Kejadian Luar Biasa (KLB). ${ }^{2}$

Diare dengan dehidrasi masih merupakan penyebab kesakitan di dunia dan pada beberapa negara berkembang sebagai penyebab utama kematian. Diare pada anak didefinisikan sebagai perubahan kebiasaan buang air besar yang normal yakni peningkatan volume $(>10 \mathrm{~mL} / \mathrm{kgbb} /$ hari) pada bayi dan anak dan/atau penurunan konsistensi feses (>3 kali dalam sehari). Diare akut umumnya terjadi kurang dari 7 hari dan tidak lebih dari 14 hari. Tingkat keparahannya dapat berhubungan dengan usia anak, status nutrisi, dan penyebab yang mendasari terjadinya diare. Diare merupakan mekanisme pertahanan tubuh, mengeliminasi organisme infeksius dengan cepat, namun dapat menimbulkan komplikasi yang serius seperti dehidrasi, khususnya pada anak malnutrisi atau keadaan imunosupresi. Diperkirakan 2 - 2,5 juta kematian yang berhubungan dengan diare terjadi pada anak kurang dari 5 tahun, dan terkonsentrasi pada daerah miskin di dunia. Perkiraan pada tahun 1990-an sekitar 1,4 juta episode diare terjadi setiap tahun pada anak kurang dari 5 tahun di negara berkembang. ${ }^{3}$

Diagnosis diare dapat ditegakkan melalui pemeriksaan fisik dan pemeriksaan penunjang. Salah satu pemeriksaan penunjang yang disarankan ialah pemeriksaan hematologi, seperti hitung rasio netrofil dan limfosit. ${ }^{4}$

\section{METODE PENELITIAN}

Jenis penelitian ini analitik retrospektif dengan memanfaatkan data catatan medik yang terdapat di Bagian Ilmu Kesehatan Anak RSUP Prof. Dr. R. D. Kandou Manado periode Januari 2010 - Maret 2014. Variabel penelitian ialah: usia, jenis kelamin. Analisis terhadap hubungan rasio neutrofil limfosit pada diare akut dengan dehidrasi dan tanpa dehidrasi menggunakan uji chi square.

\section{HASIL PENELITIAN}

Berdasarkan hasil pengumpulan data sekunder yang dilakukan secara retrospektif di Bagian Anak RSUP Prof. Dr. R.D. Kandou terhadap anak penderita diare akut dengan dehidrasi dan tanpa dehidrasi selama periode Januari 2010 - Maret 2014 ditemukan 40 kasus yang memenuhi kriteria inklusi.

Tabel 1. Distribusi frekuensi karakteristik sampel berdasarkan usia

\begin{tabular}{cccc}
\hline $\begin{array}{c}\text { Usia } \\
\text { (bulan) }\end{array}$ & $\begin{array}{c}\text { Laki- } \\
\text { laki }\end{array}$ & Perempuan & $\begin{array}{c}\text { Rerata } \\
\text { usia }\end{array}$ \\
$6-12$ & 7 & 11 & 8,5 \\
$13-24$ & 7 & 8 & 16,5 \\
$25-36$ & 2 & 5 & 33,3 \\
Jumlah & & 40 & \\
\hline
\end{tabular}

Tabel 2. Distribusi frekuensi karakteristik sampel berdasarkan jenis kelamin

\begin{tabular}{ccc}
\hline Jenis kelamin & Frekuensi & (\%) \\
\hline Laki-laki & 16 & 40,0 \\
Perempuan & 24 & 60,0 \\
Total & 40 & 100,0 \\
\hline
\end{tabular}

Tabel 3. Distribusi frekuensi sampel diare akut

\begin{tabular}{ccc}
\hline Diare Akut & Frekuensi & $\mathbf{( \% )}$ \\
\hline Dehidrasi & 14 & 35 \\
Tanpa Dehidrasi & 26 & 65 \\
Total & 40 & 100,0 \\
\hline
\end{tabular}


Tabel 4. Analisis Hubungan Rasio Neutrofil Limfosit pada Diare Akut dengan Dehidrasi dan Tanpa Dehidrasi

\begin{tabular}{|c|c|c|c|}
\hline & $\begin{array}{c}\text { Observed } \\
\mathrm{N}\end{array}$ & $\begin{array}{c}\text { Expected } \\
\mathrm{N}\end{array}$ & Residual \\
\hline Dehidrasi & 14 & 20,0 & $-6,0$ \\
\hline $\begin{array}{l}\text { Tanpa } \\
\text { dehidrasi }\end{array}$ & 26 & 20,0 & 6,0 \\
\hline Total & 40 & & \\
\hline \multicolumn{4}{|c|}{ Test Statistics } \\
\hline \multicolumn{4}{|c|}{ perlakuan } \\
\hline Chi-Square & & $3,600^{\mathrm{a}}$ & \\
\hline Df & & 1 & \\
\hline Asymp. Sig. & & ,058 & \\
\hline
\end{tabular}

\section{BAHASAN}

Pada penelitian ini ditemukan sebanyak 40 kasus diare akut dengan dehidrasi dan tanpa dehidrasi di RSUP Prof. Dr. R.D Kandou Manado selama periode Januari 2010 - Maret 2014.

\section{Karakteristik sampel}

Populasi penelitian terdiri dari anak usia 6 bulan - 3 tahun. Keadaan tersebut terjadi sangat mungkin karena usia 6 bulan - 3 tahun jumlah air susu ibu sudah mulai berkurang dan dimulai pemberian makanan sapih yang kurang nilai gizinya serta kebersihannya. ${ }^{5}$ Penelitian ini mengambil batasan usia termuda 6 bulan karena pengaruh pemberian ASI eksklusif dapat disingkirkan. Batasan usia tertua ialah 3 tahun karena faktor usia berpengaruh terhadap imunitas sehingga akan memengaruhi derajat sakit. Rerata usia subyek pada penelitian ini ialah 15,8 bulan dangan usia termuda 6 bulan dan tertua 36 bulan. Subyek penelitian terdiri dari 16 anak (40\%) berjenis kelamin laki-laki dan 24 anak (60\%) berjenis kelamin perempuan, dengan rerata usia anak lakilaki 15 bulan dan rerata usia anak perempuan 16,24 bulan. Hasil rekam medis menunjukkan bahwa usia 6 bulan lebih banyak terkena diare yaitu sebesar $15 \%$.

Status gizi buruk dapat memperpanjang durasi diare dan memperlama regenerasi epitel usus. Tatalaksana penanganan diare ialah rehidrasi menggunakan oralit baru, pemberian ASI dan makanan sapihan dengan frekuensi lebih sering, antibiotik secara rasional dan edukasi kepada orang tua. Antibiotik hanya diberikan jika ada indikasi seperti disentri, diare berdarah, kolera, dan terdapat penyakit penyerta yang mempunyai indikasi untuk diberikan antibiotik. ${ }^{5,6}$

Sesuai rekam medis yang diperoleh menunjukkan sebanyak 14 anak (35\%) menderita diare dengan dehidrasi dan 26 anak (65\%) menderita diare tanpa dehidrasi. Dari hasil rekam medis tersebut dapat dikatakan bahwa kejadian diare yang diderita anak sebelum dibawa ke rumah sakit untuk pengobatan lanjutan, orang tua telah menangani dengan pemberian oralit sebagai pencegahan utama dehidrasi.

\section{Hubungan rasio netrofil limfosit pada diare akut dengan dehidrasi dan tanpa dehidrasi}

Data rekam medis dari 40 anak yang menderita diare baik dengan dehidrasi maupun tanpa dehidrasi tercatat neutrofil dan limposit rata-rata berada pada nilai normal yaitu 20-60 untuk neutrofil normal dan 20-70 untuk limfosit normal. Walaupun terdapat beberapa anak yaitu 4 anak berada di bawah nilai normal neutrofil tetapi limfosit berada pada nilai normal, dan hanya satu anak penderita diare yang memiliki nilai neutrofit maupun limposit di bawah nilai normal.

Data rekam medis yang diperoleh berupa data neurtofil dan limfosit kemudian dianalisis rasio neutrofil limfosit dengan cara perbandingan antara nilai neurtofil dan limfosit. Hasil perbandingan tersebut kemudian dianalisis dengan menggunakan Chi-Square test. Berdasarkan hasil analisis seperti terlihat pada tabel 6 diperoleh hasil $\chi^{2}=3,60$ dengan $\mathrm{df}=1$ dan $\chi_{\text {tabel }}^{2}=3,84$ pada taraf signifikansi 5\%. Dari hasil analisis tersebut menunjukkan bahwa harga $\chi_{\text {hitung }}^{2}<\chi_{\text {tabel }}^{2}$ yaitu $3,60<3,84$, yang menunjukkan tidak terdapat hubungan antara rasio neutofil limposit pada anak penderita diare akut dengan dehidrasi dan tanpa dehidrasi. 


\section{SIMPULAN}

Berdasarkan hasil penelitian yang dilakukan di Bagian Ilmu Kesehatan Anak RSUP Prof. Dr. R. D. Kandou Manado mengenai rasio netrofil limfosit pada anak penderita diare akut dengan dehidrasi dan tanpa dehidrasi dapat disimpulkan bahwa tidak terdapat hubungan netrofil limfosit pada anak penderita diare akut dengan dehidrasi dan tanpa dehidrasi.

\section{DAFTAR PUSTAKA}

1. World Health Organization. The Treatment of Diarrhoea: a manual for Physicians and other senior health workers (4th revision). 2005. [cited 9 oktober 2014]. Available from: http://whqlibdoc.who.int/publications/2 005/924159180.pdf [Tesis]. Semarang: Universitas Diponegoro; 2010.

2. Adisasmito W. Faktor Resiko Diare Pada
Bayi dan Balita di Indonesia. Systemic Review Penelitian Akademik Bidang Kesehatan Masyarakat. Jakarta: Universitas Indonesia, 2007.

3. Manoppo JICh. Profil Diare Akut Dengan Dehidrasi Berat di Ruang Perawatan Intensif Anak. Sari Pediatri. 2010;12(3):1578-61.

4. Weizman Z, Asli G, Alsheikh A. Efect of a Probiotic Infant Formula on Infections in Child Care Centers. BioGaia. 2008;August:1-3.

5. Kurniawati F. Pengaruh suplementasi seng dan probiotik terhadap durasi diare akut cair anak [Tesis]. Semarang: Universitas Diponegoro; 2010.

6. Hani P, Santosa B, Puruhita N. Pengaruh Suplemen Seng dan Probiotik Pasca Perawatan Diare Akut Cair Anak Terhadap Kejadian Diare berulang. Sari Pediatri. 2011;13(2):96-103. 